\title{
Drug-based vector control: a potential new paradigm
}

\author{
Pedro Alonso ${ }^{1 *}$ and Dirk Engels ${ }^{2}$
}

With the vision of a malaria free world, the Global Technical Strategy for malaria 2016-2030 [1] sets ambitious, but attainable goals for the next 14 years. Based on lessons from the 1953 Global Malaria Eradication Programme, where leadership declared that all of the tools needed were at hand [2], the GTS instead highlights that innovation will need to play an important role in achieving key milestones towards malaria eradication [3]. This includes the development of new and improved tools, optimizing the use of currently available ones and enabling the rapid uptake of emerging tools, interventions and strategies [1].

Vector control, historically a key pillar of the hardwon achievements against malaria, is now challenged by insecticide resistance $[4,5]$. The impact on public health is difficult to document, and there is recent evidence from a multi-centre trial that long-lasting insecticidetreated nets remain effective in spite of variable levels of resistance to pyrethroïd insecticides [6]. However it is clear that malaria vector control, as well as interventions based on medicines, are inherently driving towards resistance, and thus both risk mitigation strategies and replacement technologies must be planned for. Furthermore, success in vector control has led to the recognition that residual transmission, mostly by outdoor biting mosquitoes, represents a significant challenge to malaria elimination efforts [7].

A new drug-based vector control strategy with ivermectin, has shown the potential to become a supplementary intervention, acting as an endectocide, a medicine causing the death of Anopheles mosquitoes when ingested in sufficient doses in a blood meal [8]. Ivermectin is an antiparasitic used extensively in mass drug administration for the control of onchocerciasis and lymphatic filariasis (LF) There is an emerging body of

\footnotetext{
*Correspondence: alonsop@who.int

${ }^{1}$ Global Malaria Programme, World Health Organization, Geneva, Switzerland

Full list of author information is available at the end of the article
}

work supporting this potential novel use of ivermectin, to potentially impact malaria transmission if used in mass drug administration.

If evidence is obtained that mass administration with ivermectin can have a safe, incremental and cost-effective impact on malaria transmission, then this new intervention could play a role in the reduction of malaria and neglected tropical diseases given the major overlap of these diseases in the tropics.

In 2016, the Global Malaria Programme (GMP) and the Department for Control of Neglected Tropical Diseases (NTD) jointly constituted a WHO Technical Consultation to evaluate the emerging evidence on this application of ivermectin and to develop a target product profile of an endectocide as malaria vector control tool. This will provide guidance to the scientific community on the kind of evidence required to develop a WHO policy recommendation on the use of ivermectin or other endectocides for malaria transmission control. The main conclusions of the consultation [9] were presented to the Malaria Policy Advisory Committee (MPAC) in September 2016. MPAC provided input on the TPP and the required evidence needed to consider a policy recommendation (clearly not on the potential intervention itself) [10]. The final TPP has been revised and is available on WHO website. We believe that this exercise of identifying the main data gaps and priorities needed for a policy recommendation on this potential novel tool will help optimize early efforts and investments. Time and a focused research and development effort will tell us whether the repurposing of this old drug, or a new endectocide, may become a new intervention to be used in improved vector control, or even become an elimination tool. At the same time it provides an opportunity also to revise and optimize the large-scale use of ivermectin for NTDs and develop products and strategies that would meet expectations for both programmes. 
This Thematic Series in the Malaria Journal is based on the extensive background review performed by the authors and contributed to the preparations and evidence presented at the WHO technical consultation.

\section{Authors' contributions}

PA and DE designed, co-ordinated and drafted the final manuscript. Both authors read and approved the final manuscript.

\section{Author details}

${ }^{1}$ Global Malaria Programme, World Health Organization, Geneva, Switzerland. ${ }^{2}$ Control of Neglected Tropical Diseases, World Health Organization, Geneva, Switzerland.

\section{Competing interests}

The authors declare they have no competing interests.

\section{Publisher's Note}

Springer Nature remains neutral with regard to jurisdictional claims in published maps and institutional affiliations.

Received: 21 April 2017 Accepted: 25 April 2017

Published online: 17 May 2017

\section{References}

1. WHO. Global technical strategy for malaria 2016-2030. Geneva: World Health Organization. http://www.who.int/malaria/publications/ atoz/9789241564991/en/. Accessed Feb 2017.
2. WHO. Official records of the eight World Health Assembly. Mexico City; 1955. http://apps.who.int/iris/bitstream/10665/85662/1/Official_ record63_eng.pdf. Accessed Feb 2017.

3. WHO. Eliminating malaria. http://apps.who.int/iris/bitstream/10665/205565/1/WHO_HTM_GMP_2016.3_eng.pdf?ua=1. Accessed Feb 2017

4. Mnzava AP, Knox TB, Temu EA, Trett A, Fornadel C, Hemingway J, et al. Implementation of the global plan for insecticide resistance management in malaria vectors: progress, challenges and the way forward. Malar J. 2015;14:173.

5. World Health Organization. Global plan for insecticide resistance management in malaria vectors (GPIRM). Geneva: World Health Organization; 2012.

6. WHO. Implications of insecticide resistance for malaria vector control. http://www.who.int/entity/malaria/news/2016/iir-malaria-vector-controlevaluation-nov2016.pdf. Accessed Feb 2016, 2017.

7. WHO-GMP. Control of residual malaria parasite transmission. Technical Note. 2014.

8. Chaccour CJ, Kobylinski KC, Bassat Q, Bousema T, Drakeley C, Alonso P, et al. Ivermectin to reduce malaria transmission: a research agenda for a promising new tool for elimination. Malar J. 2013;12:153.

9. Technical consultation meeting report. Ivermectin for malaria transmission control. Background document for Session 9 of the September 2016 MPAC meeting. http://www.who.int/malaria/mpac/mpac-sept2016invermectin-session9.pdf?ua=1. Accessed Feb 2017.

10. WHO. Malaria Policy Advisory Committee (MPAC) meeting report. 2016 http://www.who.int/malaria/publications/atoz/mpac-report-september-2016/en/. Accessed Feb 2017.

Submit your next manuscript to BioMed Central and we will help you at every step:

- We accept pre-submission inquiries

- Our selector tool helps you to find the most relevant journal

- We provide round the clock customer support

- Convenient online submission

- Thorough peer review

- Inclusion in PubMed and all major indexing services

- Maximum visibility for your research

Submit your manuscript at www.biomedcentral.com/submit
() Biomed Central 